\title{
URBAN-RURAL DISPARITIES IN THE UTILIZATION OF PRIMARY HEALTH CARE CENTER AMONG ELDERLY IN EAST JAVA, INDONESIA
}

\author{
Disparitas Perkotaan-Perdesaan dalam Pemanfaatan Puskesmas di antara Lansia di \\ Jawa Timur, Indonesia
}

\author{
Ratna Dwi Wulandari', Agung Dwi Laksono² \\ ${ }^{1}$ Faculty of Public Health, University of Airlangga, Indonesia \\ ${ }^{2}$ National Institute of Health Research and Development, Ministry of Health, Indonesia. \\ Email: ratna-d-w@fkm.unair.ac.id.
}

\begin{abstract}
Introduction: Urban always attracts investors to invest. Health facilities in urban areas are growing rapidly compared to villages. This condition is estimated to contribute to the disparity of urban-rural areas in the utilization of health services. Studying the utilization of health services is a way to evaluate the performance of the health care system through its output.

Aim: This study was intended to analyze urban-rural disparity in the utilization of primary health care or puskesmas use by the elderly.

Methods: This study was used the 2013 Riskesdas (Indonesian Basic Health Survey) raw data. The 2013 Riskesdas was designed a cross-sectional survey. With the multi-stage cluster random sampling method, 25,813 elderly people in East Java Province were obtained. Data were analyzed using Multinomial Logistic Regression tests.

Results: Elderly people in urban areas have a better probability of outpatient use of 1.208 than those living in rural areas (OR 1.208; 95\% Cl 1.057-1.380). The elderly who have a primary school and under education have the possibility of 1.558 times more utilizing outpatients in the puskesmas than the elderly who have college education levels (OR 1.558; 95\% Cl 1.001-2.424).

Conclusions: There was a disparity between urban and rural areas in the utilization of outpatient puskesmas in East Java by the elderly. Policy makers in East Java are recommended to improve facilities and infrastructure of the puskesmas in rural areas by paying attention to the results of this study.
\end{abstract}

Keywords: elderly, urban-rural disparities, primary health care center, healthcare utilization, East Java, inpatientoutpatient

\begin{abstract}
ABSTRAK
Pendahuluan: Perkotaan selalu lebih menarik investor untuk berinvestasi. Fasilitas kesehatan di perkotaan berkembang pesat dibanding desa. Kondisi ini diperkirakan turut mendorong terjadinya disparitas perkotaanperdesaan dalam pemanfaatan pelayanan kesehatan. Mempelajari pemanfaatan layanan kesehatan adalah cara untuk mengevaluasi kinerja sistem perawatan kesehatan melalui output-nya.

Tujuan: Penelitian ini dimaksudkan untuk menganalisis disparitas perkotaan-perdesaan dalam pemanfaatan Puskesmas oleh lansia.

Metode:. Penelitian ini menggunakan data mentah Riskesdas (Riset Kesehatan Dasar) tahun 2013. Riskesdas dirancang sebagai survei cross-sectional. Dengan metode multi-stage cluster random sampling didapatkan 25.813 lansia. Data dianalisis menggunakan uji Regresi Logistik Multinomial.

Hasil: Lansia di daerah perkotaan memiliki kemungkinan yang lebih baik untuk penggunaan rawat jalan 1,208 kali daripada mereka yang tinggal di daerah perdesaan (OR 1,208; 95\% Cl 1,057-1,380). Lansia dengan Pendidikan SD ke bawah memiliki kemungkinan 1,558 kali lebih banyak memanfaatkan rawat jalan di Puskesmas daripada lansia dengan pendidikan perguruan tinggi (OR 1,558; 95\% Cl 1,001-2,424).
\end{abstract}




\begin{abstract}
Kesimpulan: Ada disparitas antara daerah perkotaan dan perdesaan dalam pemanfaatan Puskesmas di Jawa Timur oleh lansia dalam kategori rawat jalan. Policy maker di Jawa Timur direkomendasikan untuk memperbaiki sarana dan prasarana Puskesmas di wilayah perdesaan dengan memperhatikan poin hasil penelitian ini.
\end{abstract}

Kata kunci: lansia, disparitas perkotaan-perdesaan, Puskesmas, pemanfaatan pelayanan kesehatan, Jawa Timur, rawat jalan-rawat inap.

Received: 15 January 2019

Accepted: 5 March 2019

Published: 24 May 2019

\section{INTRODUCTION}

The World Health Organization (WHO) as an organization is responsible for public health worldwide by being aware of elderly as one of vulnerable groups. Apart from children, pregnant women, malnourished people, and sick people, WHO includes elderly in the vulnerable groups (World Health Organization, 2018).

A primary health care center (Puskesmas) is a technically implemented unit of a health office to carry out health development in a district/city level. Puskesmas has a strategic role in communitites as an entrance before they get to be referred to advanced health services like a hospital (Tebay, 2018; Hamzah and Tamba, 2018). Puskesmas provide outpatient and inpatient emergency services. Inpatient services in the puskesmas are often provided due to inaccessible hospitals (Sari Rochman et al., 2018).

East Java is one of the provinces with a significant increase in the elderly population, $10.35 \%$ in 2010 to $13.09 \%$ in 2019 (BPS Provinsi Jawa Timur, 2019). This condition has made the East Java provincial government make geriatrics one of the priority programs by realizing Elderly Friendly Health Centers (Dinas Kesehatan Provinsi Jawa Timur, 2018).

Studying the utilization of health services is a way to evaluate the performance of health care system as its output. Other outputs that can assess the performance of the health care system are equity (Brydsten, Hammarström and San Sebastian, 2018; Tayyari Dehbarez et al., 2018), acceptability (Laksono and Rachmawaty, 2013), accessibility (Song et al., 2018; Mubasyiroh, Nurhotimah and Laksono, 2016), effectiveness (Rinaldi, Kiadaliri and HaghparastBidgoli, 2018), and efficiency (Yildiz, Heboyan and Khan, 2018).

The disparity of health services between urban and rural areas is always interesting to study because many things can be found in this case. One of different characteristics of urban and rural areas is the accelerating development. Urban areas tend to develop faster than rural ones do especially in the health sector. Investors are more interested in investing health facilities in urban areas because they grow rapidly with a variety of more modern medical equipment. The density of occupancy makes health development concentrated in urban areas. If it is not controlled properly, it will cause huge inequality between urban and rural. This case must be scrutinized to give an idea about imbalanced access of rural-urban communities' rights (Holliday et al., 2017; Yu, Matthes and Wei, 2018;
Li et al., 2018). In fact, according to the principle of right equality, there should not be a difference in the fulfillment of right to health wherever the communities settle. Research examining the disparity can be a consideration for the government to improve health facilities in rural areas. The government must be responsible for minimizing the disparity (Fu et al., 2018; Karuaihe and Wandschneider, 2018; Wong and Szeto, 2018; Li, Yao and Yin, 2018; Song, Shin and Kim, 2018).

Based on this issue, this study was aimed to analyze the urban-rural disparity in the use of puskesmas by elderly in East Java Province, Indonesia. By looking further at the disparity in the performance of healthcare system as an output, it can be deliberation for policymakers to make better policies of healthcare system (Megatsari et al., 2018), as well as budgeting policies to strengthen less paramount outputs (Pratiwi et al., 2014).

\section{METHODS}

This research involved elderly aged 50 years and over (Laksono, Nantabah and Wulandari, 2018; Wulandari et al., 2019). The raw data came from basic health research or Riskesdas in 2013. The population in this study were elderly throughout East Java. With a stratified cluster-random sampling, as many as 25,813 elderly respondents in East Java Province were involved (National Institute of Health Research and Development of Ministry of Health of the Republic of Indonesia, 2013).

Based on the operational definition, utilization of puskesmas meant that elderly used outpatient and inpatient puskesmas. The data included the utilization of last-month outpatient services and last-year inpatient services by the elderly. From this limitation, it was assumed that the elderly could still remember every outpatient and inpatient situation well. The variable in this research included insurance ownership as the respondent's acknowledgment of insurance ownership, such as no insurance, public insurance (Askes, Jamkesmas, Jamkesda, Jamsostek), and private insurance. Socioeconomic status is an index of the quintile for goods ownership stated by the respondents (National Institute of Health Research and Development of Ministry of Health of the Republic of Indonesia, 2013).

The t-test was used to test the age variable in the other variable categories while Chi-Square was used to examine 9 (nine) dichotomous variables, such 
as utilization of puskesmas, gender, marital status, education, employment, socioeconomic condition, insurance, travel time, and transportation cost to puskesmas. This statistical test was used to find whether the use of puskesmas in the urban and rural areas by the elderly was significantly different or not. Besides, the multinomial logistic regression was used to study the disparity of hospital use by the elderly in rural and urban areas, as well as to assess the significance level (Xu et al., 2018).

\section{RESULTS AND DISCUSSION}

Figure 1 and 2 describe the utilization of puskesmas based on residence. The picture shows similar characteristics. Middle-class elderly dominated to use outpatient health services in urban areas while elderly with high socioeconomic status utilized more outpatient health services in rural areas. The same results were found in the use of inpatient health services in both areas.

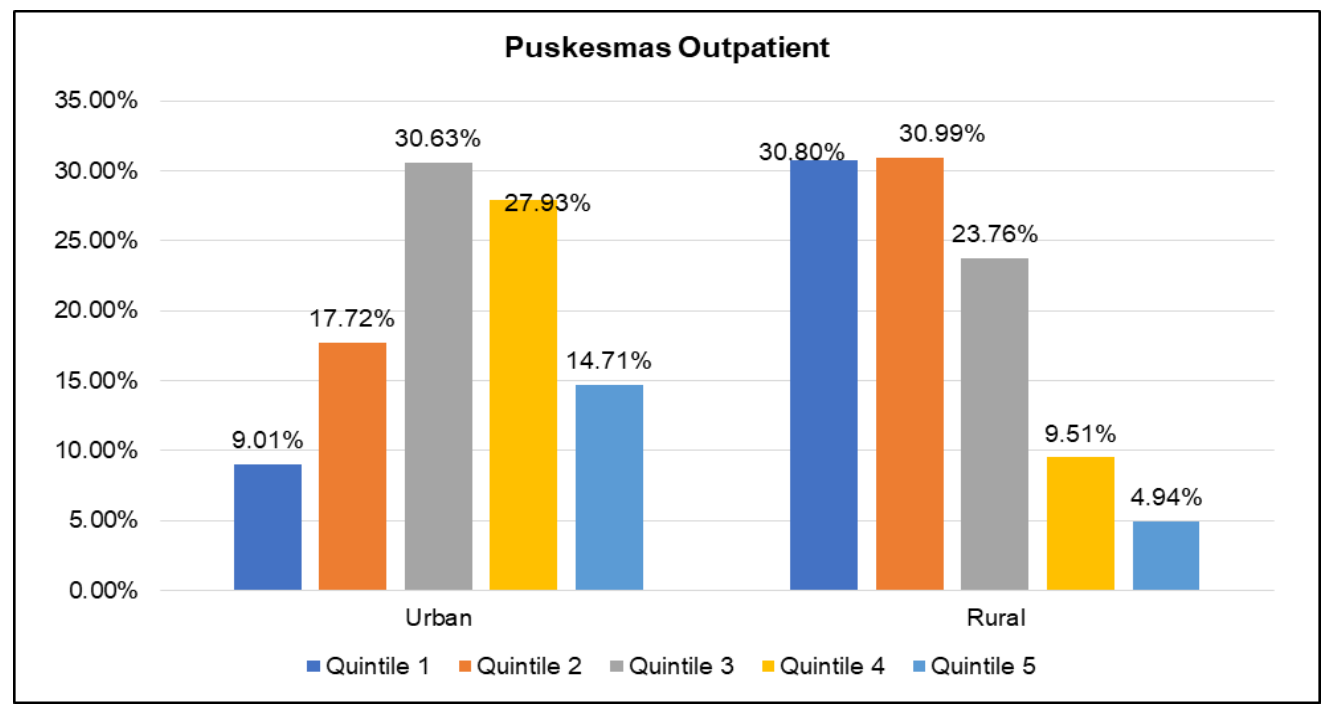

Figure 1. The utilization of puskesmas outpatient in East Java Elderly based on areas (urban-rural) and socioeconomic status

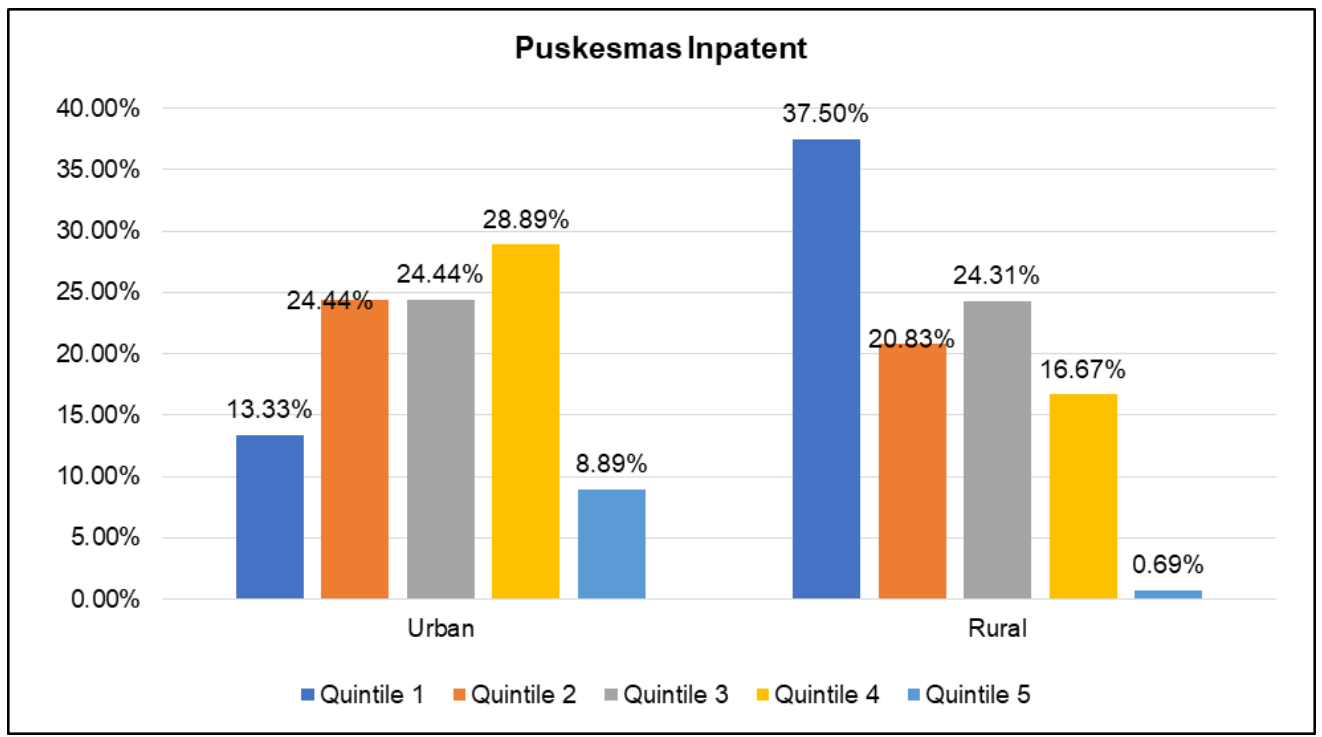

Figure 2. The utilization of puskesmas inpatient in East Java Elderly based on areas (urban-rural) and socioeconomic status

Table 1 shows that there is a disparity in the utilization of puskesmas in urban and rural areas. The disparity was significantly different. Based on Table 1, the elderly in rural areas had a slightly older age in average (61.91 years) than those in urban areas. Based on gender, both regions were dominated by females. Even though the proportion was almost 
balanced, the gender variable was not significantly different in using puskesmas.

Table 1 shows that both urban and rural areas were dominated by those who are married although $0.9 \%$ of the unmarried elderly lived there. Table 1 also shows that East Java were dominated by the elderly who had low education like primary school and under. In rural areas this figure is very high, reaching $93.0 \%$ of the elderly who live in rural East Java province. While in urban areas there are around $68.0 \%$.

Based on employment, urban areas were mostly dominated by the unemployed elderly. In contrast, the elderly in rural areas of East Java worked as farmers, fisherman, or labor. Statistically, this difference confirmed to be significant. Table 1 shows the different socioeconomic characteristics of the elderly in East Java. In urban areas, most of the elderly came from high socioeconomic levels (Quintile 4 and 5 at $50.6 \%$ ). Meanwhile, most of the elderly in rural areas had low socioeconomic status (Quintile 1 and 2 at $58.7 \%)$.

Table 1 shows that in both regions, most of the elderly did not have insurance. For those who have insurance, the insurance was a public insurance managed by the government. Based on length of travel to puskesmas, the elderly in urban areas had shorter time to reach puskesmas. Meanwhile, based on transportation costs to puskesmas, transportation cost of > IDR 5,000 was dominant in rural areas although rural areas have higher percentage $(60.3 \%)$. The three variables were statistically significant.

The results of multinomial logistic regression can be seen in Table 2. This test was conducted to detect disparity in the utilization of puskesmas by the elderly in urban and rural areas of East Java. Table 2 shows that the disparity in the utilization of puskesmas was found in outpatient services. The elderly in urban areas had better probable use of outpatient servises of 1.208 than those in rural areas (OR 1.208; 95\% CI 1.057-1.380). Meanwhile, the elderly in rural areas better used inpatient services. Yet, this was not statistically significant.

The findings in this study indicate that there was no significant difference in the use of inpatient services by the elderly in rural areas and urban areas. Thereby, the level of utilization of the inpatient services by the elderly in both areas was relatively the same. The findings shows that the conditions where the elderly utilized inpatient services were non-negotiable. In terms of accessibility, the elderly in rural areas had worse access than those in urban ones. However, if they need more advanced treatment and hospitalization, they will be undertaken. This was what distinguishes the use of outpatient services in rural areas and urban areas. The elderly rarely used outpatient services maybe because of the distant location. Even though there are complaints, they will not refer them to the health office. As a result, their disease tends to be severe and directly requires an inpatient treatment (Gonzales et al., 2017; Lungu et al.,
2018). Table 2 shows that age variable also influences the use of puskesmas like the use of inpatient services. Table 2 also shows that the education level also influences the use of outpatient services. The elderly who undergraduated from a primary school and under had more possibility of 1.558 times in using outpatient services in puskesmas than the elderly who graduated from college (OR 1.558; 95\% Cl 1.001-2.424). The older the elderly are, the more inevitable they suffer from disease. This condition allows them to utilize higher health facilities (Chiapella, Menna and Mamprin, 2018). The elderly with a lower level of education used more outpatient services, and the possibility of elderly morbidity based on education was higher. The higher level of morbidity can be caused by the elderly's unhealthy lifestyle and low level of education. The ability to promote preventive action is lower so that their physical condition becomes more vulnerable. Elderly with the higher education have better ability to absorb information about health so that their health behavior is better (Hahn, Truman and Williams, 2018; Kusumawardani et al., 2018).

Elderly can be considered as vulnerable groups. Because of their vulnerability, the elderlies are relatively more difficult to mobile. Data show that many elderlies had degenerative diseases. These further limit their movement. Besides, many elderly live together as husband and wife because their children already have their own house, even live in other cities. By that, elderly health is unnoticed unless the elderly are truly ill that result in serious consequences. The results of this study can be consideration to improve health program targeting the elderly (Putri and Riasmini, 2013; Fu et al., 2018).

Based on the information in Table 2, socioeconomic status also has a significant influence on the use of puskesmas by the elderly. The elderly with the socioeconomic level of quintile 1 (the poorest) were likely to use outpatient services 1.342 times more than those with the quintile 5 (the richest) (OR 1.342; $95 \% \mathrm{Cl} 1.209-1.750)$. Meanwhile, in terms of the use of inpatient services, the elderly with the socioeconomic level of quintile 1 had 3.153 more beneficiaries than those who were in the quintile 5. The elderly in the quintile 1 (very poor) used outpatient services in puskesmas higher than the quintile above. Likewise for the use of outpatient services, some references found a correlation between the level of socioeconomics and healthy lifestyle. Economic limitations make people trapped in unhealthy situations and behavior, such as unhealthy housing and unbalanced eating patterns (Yuan et al., 2018; Telleen et al., 2012; Dhruve, Badgaiyan and Pandey, 2016; Kusumawardani et al., 2018). Table 2 shows that insurance ownership also influences the use of outpatient and inpatient services in puskesmas. The elderly who had public insurance managed by the government had more possibility of 2.349 times in utilizing outpatient services in puskesmas than those who owned private insurance. Meanwhile, in terms of utilization of inpatient services, 
the elderly with public insurance were likely to use $1,603,864.592$ times more than the elderly with private insurance (OR 1,603,864.592; 95\% Cl 1,603,864.592$1,603,864.592)$. The study on the effect of insurance usage have often been conducted. The results of the study showed a positive correlation (El-Sayed, Vail and Kruk, 2018; Johar et al., 2018; Lee et al., 2018).

Table 1. Statistic description of puskesmas utilization by elderly in East Java-Indonesia using the 2013 Riskesdas

\begin{tabular}{|c|c|c|c|c|}
\hline \multirow{2}{*}{ CHARACTERISTIC } & \multicolumn{2}{|c|}{ AREA } & \multirow{2}{*}{ ALL } & \multirow{2}{*}{$\mathbf{P}$} \\
\hline & URBAN & RURAL & & \\
\hline Utilization of Primary health care centers & & & & 0.000 \\
\hline - Outpatient & $666(5.1 \%)$ & $526(4,1 \%)$ & $1,192(4.6 \%)$ & \\
\hline - Inpatient & $90(0.7 \%)$ & $144(1.1 \%)$ & $234(0.9 \%)$ & \\
\hline - No utilization & $12,326(94.2 \%)$ & $12,061(94.7 \%)$ & $24,387(94.5 \%)$ & \\
\hline Age (mean) & $13,082(61.12)$ & $12,731(61.91)$ & $25,813(61.51)$ & 0,000 \\
\hline Gender & & & & 0.934 \\
\hline - Male & $6,169(47.2 \%)$ & $6,010(47.2 \%)$ & $12,719(47.2 \%)$ & \\
\hline - Female (Ref.) & $6,913(52.8 \%)$ & $6,721(52.8 \%)$ & $13,634(52.8 \%)$ & \\
\hline Marital status & & & & 0.000 \\
\hline - Never married & $143(1.1 \%)$ & $86(0.75 \%)$ & $229(0.9 \%)$ & \\
\hline - Married & $9,615(73.5 \%)$ & $9,513(74.7 \%)$ & $19,128(74.1 \%)$ & \\
\hline - Divorce (Ref.) & $3,324(25.4 \%)$ & $3,132(24.6 \%)$ & $6,456(25.0 \%)$ & \\
\hline Education level & & & & 0.000 \\
\hline - Primary school and under & $8,901(68.0 \%)$ & $11,842(93.0 \%)$ & $20,743(80.4 \%)$ & \\
\hline • Junior high school & $1,438(11.0 \%)$ & $463(3.6 \%)$ & $1,901(7.4 \%)$ & \\
\hline - Senior high school & $1,846(14.1 \%)$ & $262(2.1 \%)$ & $2,108(8.2 \%)$ & \\
\hline - College (Ref.) & 897 (96.9\%) & $164(1.3 \%)$ & $1,061(4.1 \%)$ & \\
\hline Work type & & & & 0.000 \\
\hline - No work & $5,458(41.7 \%)$ & $3,919(30.8 \%)$ & $9,377(36.3 \%)$ & \\
\hline - Gov. Employee & $594(4.5 \%)$ & $153(1.2 \%)$ & $747(2.9 \%)$ & \\
\hline - Employee & $803(6.1 \%)$ & $219(1.7 \%)$ & $1,022(4.0 \%)$ & \\
\hline - Entrepreneur & $2,510(19.2 \%)$ & $1,069(8.4 \%)$ & $3,579(13.9 \%)$ & \\
\hline - Farmer/Fisherman/Labor & $3,158(24.1 \%)$ & $7,074(55.6 \%)$ & $10,232(39.6 \%)$ & \\
\hline - Others (Ref.) & $559(4.3 \%)$ & $297(2.3 \%)$ & $8563.3 \%)$ & \\
\hline Socioeconomic status & & & & 0.000 \\
\hline - Quintile 1 & $1,085(8.3 \%)$ & $3,799(29.8 \%)$ & $4,883(18.9 \%)$ & \\
\hline - Quintile 2 & $1,944(14.9 \%)$ & $3,678(28.9 \%)$ & $5,622(21.8 \%)$ & \\
\hline - Quintile 3 & $3,438(26.3 \%)$ & $2,927(23.0 \%)$ & $6,365(24.7 \%)$ & \\
\hline - Quintile 4 & $3,753(28.7 \%)$ & $1,613(12.7 \%)$ & $5,366(20.8 \%)$ & \\
\hline - Quintile 5 (Ref.) & $2,862(21.9 \%)$ & $714(5.6 \%)$ & $3,576(13.9 \%)$ & \\
\hline Insurance & & & & 0.000 \\
\hline - No insurance & $6,809(52.0 \%)$ & $7,509(59.0 \%)$ & $14,318(55.5 \%)$ & \\
\hline - Government-run Insurance & $5,946(45.5 \%)$ & $5,197(40.8 \%)$ & $11,143(43.2 \%)$ & \\
\hline - Private-run Insurance (Ref.) & $327(2.5 \%)$ & $25(0.2 \%)$ & $352(1.4 \%)$ & \\
\hline Travel time & & & & 0.000 \\
\hline$\bullet \leq 10$ Minutes & $6,685(51.1 \%)$ & $3,311(26,0 \%)$ & $9,996(38.7 \%)$ & \\
\hline - > 10 Minutes (Ref.) & $6,397(48.9 \%)$ & $9,420(74.0 \%)$ & 15,817 (61.3\%) & \\
\hline Transportation Cost & & & & 0.000 \\
\hline$\bullet \leq \operatorname{IDR} 5,000$ & $6,435(49.2 \%)$ & $5,050(39.7 \%)$ & $11,485(44.5 \%)$ & \\
\hline • > IDR 5,000 (Ref.) & $6,647(50.8 \%)$ & $7,681(60.3 \%)$ & $14,328(55.5 \%)$ & \\
\hline
\end{tabular}

Note: Chi-Square test was used for dichotomous variables and T-test for continuous variables 
Table 2. Multinomial logistic regression for utilization of puskesmas by elderly in East Java-Indonesia using the 2013 Riskesdas

\begin{tabular}{lcccccc}
\hline \multirow{2}{*}{ Utilization (a) } & \multicolumn{3}{c}{ Outpatient (95\% Cl) } & \multicolumn{3}{c}{ Inpatient (95\% Cl) } \\
\cline { 2 - 7 } & OR & $\begin{array}{c}\text { Upper } \\
\text { Bound }\end{array}$ & $\begin{array}{c}\text { Lower } \\
\text { Bound }\end{array}$ & OR & Upper Bound & Lower Bound \\
\hline Area: Urban & $1.208^{*}$ & 1.057 & 1.380 & 0.745 & 0.554 & 1.002 \\
Age & 0.996 & 0.989 & 1.003 & $1.023^{*}$ & 1.008 & 1.037 \\
Marital Status: never married & 0.631 & 0.293 & 1.359 & $4.75 \mathrm{E}-007$ & 0.000 & $(\mathrm{~b})$ \\
Marital Status: married & 0.982 & 0.852 & 1.133 & 1.329 & 0.960 & 1.838 \\
Edu: primary school \& under & $1.558^{*}$ & 1.001 & 2.424 & 1.004 & 0.324 & 3.115 \\
Edu: junior high school & 1.330 & 0.830 & 2.132 & 0.499 & 0.136 & 1.823 \\
Edu: senior high school & 0.860 & 0.537 & 1.376 & 0.349 & 0.088 & 1.390 \\
Work: No work & 1.095 & 0.796 & 1.505 & 1.215 & 0.526 & 2.808 \\
Work: Gov. Employee & 0.649 & 0.357 & 1.180 & 0.312 & 0.032 & 3.066 \\
Work: Employee & 0.697 & 0.438 & 1.110 & 1.430 & 0.475 & 4.304 \\
Work: Entrepreneur & 0.882 & 0.625 & 1.244 & 1.326 & 0.545 & 3.225 \\
Work: Farmer/fisherman /labor & 0.770 & 0.558 & 1.063 & 1.109 & 0.482 & 2.551 \\
Socioeconomic: quintile 1 & $1.342^{*}$ & 1.029 & 1.750 & $3.153^{*}$ & 1.465 & 6.784 \\
Socioeconomic: quintile 2 & $1.380^{*}$ & 1.074 & 1.772 & $2.240^{*}$ & 1.042 & 4.818 \\
Socioeconomic: quintile 3 & $1.370^{*}$ & 1.082 & 1.735 & $2.422^{*}$ & 1.146 & 5.115 \\
Socioeconomic: quintile 4 & 1.166 & 0.922 & 1.475 & $3.001^{*}$ & 1.436 & 6.271 \\
Insurance: Not insured & 1.192 & 0.553 & 2.569 & $1,162,693.851^{*}$ & $895,002.375$ & $1,510,450.731$ \\
Insurance: Government-run & $2.349^{*}$ & 1.093 & 5.052 & $1,603,864.592^{*}$ & $1,603,864.592$ & $1,603,864.592$ \\
Travel time: $\leq 10$ minutes & $1.296^{*}$ & 1.141 & 1.473 & 1.152 & 0.859 & 1.544 \\
Transport. Cost: $\leq$ IDR 5,000 & $1.457^{*}$ & 1.290 & 1.646 & 0.971 & 0.740 & 1.273 \\
\hline
\end{tabular}

Note: $\quad$ (a) The reference category was "no utilization"; (b) Floating point overflow occurred while computing this statistic. Its value is therefore set to system missing; * Significant at level $95 \%$.

Length of travel and transportation cost also had a significant effect on the utilization of outpatient services in puskesmas. The elderly who spent $\leq 10$ minutes to puskesmas had probability of 1.296 times better to use outpatient services than those who spent $>10$ minutes (OR 1.296; 95\% Cl 1.141-1.473). Regarding the transportation cost, the elderly who paid $\leq$ IDR 5,000 were likely to use outpatient services 1.457 times than the elderly who spent > IDR 5,000 (OR 1.457; 95\% Cl 1.290-1.646). The accessibility of health facilities for elderly in urban areas is better. The distance to health facilities in urban areas is closer, and the length of travel is quicker. Also, the transportation access is easier. This condition causes the barrier for elderly to go to health facilities. Meanwhile, some barriers for the elderly in rural areas include longer distance, long time, and more difficult transportation. The more barriers they face, the longer they tend to delay treatment. Thus, they are unable to hold back anymore (Carrillo et al., 2011; Chuah et al., 2018; Laksono, Nantabah and Wulandari, 2018).

According to studies on health-seeking behavior, it was also found that there was a different pattern of treatment seeking in urban and rural communities. Aside from the access, the socio-cultural differences in urban and rural communities also influence public responses towards the complaints emerging in urban and rural communities. The accessible health facilities and fast flow of information in urban areas tend to make people easily come to health facilities. If there were a few complaints, urban community will immediately seek for treatment in health facilities. Unlike poeple in cities, elderly in rural areas are constrained by access, such as geographical access, length of travel, and transportation (Suharmiati, Laksono and Astuti, 2013; Langley, Wootton and Grieve, 2018; Song et al., 2018).

\section{CONCLUSION}

Based on the results of this study, it can be concluded that there is a disparity in the use of outpatient services in puskesmas by elderly who lived both urban and rural areas of East Java. The elderly who lived in urban areas were likely to use more than those who lived in rural areas. The disparity in the utilization of puskesmas by the elderly was also influenced by education level, socioeconomic level, insurance ownership, length of travel, and transportation cost. To reduce or minimize the disparity 
in the utilization of puskesmas by the elderly in East Java, policymakers can use the findings as a cornerstone on the equality of service policy. The results of this study are superficial, further research is needed to find out the reasons individually with a qualitative approach.

\section{REFERENCE}

BPS Provinsi Jawa Timur (2019) Persentase Penduduk Lansia Hasil Proyeksi Penduduk Menurut Kabupaten/Kota di Jawa Timur, 2010$2020 . \quad$ Available at: https://jatim.bps.go.id/dynamictable/2018/02/06 /328/persentase-penduduk-lansia-hasilproyeksi-penduduk-menurut-kabupaten-kotadi-jawa-timur-2010-2020.html (Accessed: 20 February 2019).

Brydsten, A., Hammarström, A. and San Sebastian, M. (2018) 'Health inequalities between employed and unemployed in northern Sweden: A decomposition analysis of social determinants for mental health', International Journal for Equity in Health, 17(1). doi: 10.1186/s12939018-0773-5.

Carrillo, J. E. et al. (2011) 'Defining and targeting health care access barriers.', Journal of health care for the poor and underserved, 22(2), pp. 562-75. doi: 10.1353/hpu.2011.0037.

Chiapella, L. C., Menna, J. M. and Mamprin, M. E. (2018) 'Potentially Inappropriate Medications in Elderly Ambulatory Patients: A Comparative Study between a Primary Health Care Center and a Community Pharmacy', Value in Health Regional Issues, 17, pp. 119-125. doi: 10.1016/j.vhri.2017.12.009.

Chuah, F. L. H. et al. (2018) 'The health needs and access barriers among refugees and asylumseekers in Malaysia: A qualitative study', International Journal for Equity in Health, 17(1). doi: 10.1186/s12939-018-0833-x.

Dhruve, S., Badgaiyan, Y. D. and Pandey, S. (2016) 'A Study of Socio Economic Factors Affecting Family Planning Services in An Urban Area', International Journal of Scientific Research, 5(6), pp. 618-620. Available at: https://www.researchgate.net/publication/3169 41142.

Dinas Kesehatan Provinsi Jawa Timur (2018) RENCANA KERJA DINAS KESEHATAN PROVINSI JAWA TIMUR TAHUN 2018. Surabaya.

El-Sayed, A. M., Vail, D. and Kruk, M. E. (2018) 'Ineffective insurance in lower and middle income countries is an obstacle to universal health coverage', Journal of global health, 8(2). doi: 10.7189/jogh.08.020402.

$\mathrm{Fu}, \mathrm{X}$. et al. (2018) 'Influencing factors of inequity in health services utilization among the elderly in
China 14 Economics 1402 Applied Economics 11 Medical and Health Sciences 1117 Public Health and Health Services', International Journal for Equity in Health, 17(1). doi: 10.1186/s12939-018-0861-6.

Gonzales, S. et al. (2017) 'Progressive rural-urban disparity in acute stroke care', Neurology, 88(5), pp. 441-448. doi: 10.1212/WNL.0000000000003562.

Hahn, R. A., Truman, B. I. and Williams, D. R. (2018) 'Civil rights as determinants of public health and racial and ethnic health equity: Health care, education, employment, and housing in the United States', SSM - Population Health, 4, pp. 17-24. doi: 10.1016/j.ssmph.2017.10.006.

Hamzah, O. S. and Tamba, L. (2018) 'Determinants of implementation of bureaucracy behavior in health service in community health center', Indian Journal of Public Health Research and Development, 9(3), pp. 292-296. doi: 10.5958/0976-5506.2018.00225.5.

Holliday, T. L. et al. (2017) 'Disparities in rural breast cancer care: Factors affecting choice of breast reconstruction in a West Virginia Tertiary Care Hospital', American Surgeon, 83(7).

Johar, M. et al. (2018) 'Inequality in access to health care, health insurance and the role of supply factors', Social Science and Medicine, 213, pp. 134-145.

doi: 10.1016/j.socscimed.2018.07.044.

Karuaihe, S. T. and Wandschneider, P. R. (2018) 'Limited access to services for the urban poor in Windhoek, Namibia', Development Southern Africa, 35(4), pp. 466-479. doi: 10.1080/0376835X.2018.1475219.

Kusumawardani, N. et al. (2018) 'Socio-economic, demographic and geographic correlates of cigarette smoking among Indonesian adolescents: results from the 2013 Indonesian Basic Health Research (RISKESDAS) survey', Global Health Action, 11. doi: 10.1080/16549716.2018.1467605

Laksono, A. D., Nantabah, Z. K. and Wulandari, R. D. (2018) 'Access Barriers to Health Center for Elderly in Indonesia', Buletin Penelitian Sistem Kesehatan, 21(4), pp. 228-235. doi: 10.22435/hsr.v2li4.887.

Laksono, A. D. and Rachmawaty, T. (2013) 'Akseptabilitas Bidan terhadap Implementasi Kebijakan Jaminan Persalinan di Kabupaten Mojokerto', Buletin Penelitian Sistem Kesehatan, 16(4), pp. 341-349.

Langley, E. L., Wootton, B. M. and Grieve, R. (2018) 'The Utility of the Health Belief Model Variables in Predicting Help-Seeking Intention for Anxiety Disorders', Australian Psychologist, 53(4), pp. 291-301. doi: 10.1111/ap.12334.

Lee, Y.-H. et al. (2018) 'Growing concerns and controversies to Taiwan's National Health Insurance-what are the lessons from mainland 
China, South Korea and Singapore?', International Journal of Health Planning and Management, 33(1), pp. e357-e366. doi: 10.1002/hpm.2387.

Li, C., Yao, N. A. and Yin, A. (2018) 'Disparities in dental healthcare utilization in China', Community Dentistry and Oral Epidemiology. doi: $10.1111 /$ cdoe. 12394 .

$\mathrm{Li}$, J. et al. (2018) 'Urban-rural disparities in health care utilization among Chinese adults from 1993 to 2011', BMC health services research, 18(102), pp. 1-9. doi: 10.1186/s12913-018-2905-4.

Lungu, E. A. et al. (2018) 'What influences where they seek care? Caregivers' preferences for underfive child healthcare services in urban slums of Malawi: A discrete choice experiment', PLOS ONE, 13(1). doi: 10.1371/journal.pone.0189940.

Megatsari, H. et al. (2018) 'Community Perspective about Health Services Access', Buletin Penelitian Sistem Kesehatan, 21, pp. 247-253. doi: 10.22435/hsr.v2li4.231.

Mubasyiroh, R., Nurhotimah, E. and Laksono, A. D. (2016) 'Indeks Aksesibilitas Pelayanan Kesehatan di Indonesia', in Supriyanto, S. Chalidyanto, D., and Wulandari, R. D. (eds) Aksesibilitas Pelayanan Kesehatan di Indonesia. Jogjakarta: PT Kanisius, pp. 21-58.

National Institute of Health Research and Development of Ministry of Health of the Republic of Indonesia (2013) The 2013 Indonesia Basic Health Survey (Riskesdas): National Report. Jakarta.

Pratiwi, N. L. et al. (2014) 'Kajian Kebijakan Penyaluran Dana Bantuan Operasional Kesehatan dalam Mendukung Pencapaian Kesehatan Ibu dan Anak (MDG's 4,5) di Tiga Kabupaten, Kota di Provinsi Jawa Timur Indonesia', Buletin Penelitian Sistem Kesehatan, 17(4), pp. 395405.

Putri, Y. S. E. and Riasmini, N. M. (2013) 'The Predictors of Caregiver's Burden and Depression Level in Caring Elderly People with Dementia at Community', Jurnal Ners, 8(1), pp. 88-97. doi: 10.20473/jn.v8i1.3882.

Rinaldi, G., Kiadaliri, A. A. and Haghparast-Bidgoli, H. (2018) 'Cost effectiveness of HIV and sexual reproductive health interventions targeting sex workers: A systematic review', Cost Effectiveness and Resource Allocation, 16(1). doi: 10.1186/s12962-018-0165-0.

Sari Rochman, E. M. et al. (2018) 'Method Extreme Learning Machine for Forecasting Number of Patients' Visits in Dental Poli (A Case Study: Community Health Centers Kamal Madura Indonesia)', Journal of Physics: Conference Series, 953(1). doi: 10.1088/1742 6596/953/1/012133.

Song, I. G., Shin, S. H. and Kim, H.-S. (2018) 'Improved regional disparities in neonatal care by government-led policies in Korea', Journal of
Korean Medical Science, 33(6). doi: 10.3346/jkms.2018.33.e43.

Song, Y. et al. (2018) 'Spatial and temporal variations of spatial population accessibility to public hospitals: a case study of rural-urban comparison', GIScience and Remote Sensing, 55(5), pp. 718-744. doi: 10.1080/15481603.2018.1446713.

Suharmiati, Laksono, A. D. and Astuti, W. D. (2013) 'Review Kebijakan tentang Pelayanan Kesehatan Puskesmas di Daerah Terpencil Perbatasan', Buletin Penelitian Sistem Kesehatan, 16(2), pp. 109-116.

Tayyari Dehbarez, N. et al. (2018) 'Does free choice of hospital conflict with equity of access to highly specialized hospitals? A case study from the Danish health care system', Health Policy. doi: 10.1016/j.healthpol.2018.04.006.

Tebay, V. (2018) 'The strategy in improving quality of health services for patient satisfaction in community health clinic (Puskesmas) North Jayapura, Jayapura City', Indian Journal of Public Health Research and Development, 9(4), pp. 189-193. doi: 10.5958/09765506.2018.00281.4

Telleen, S. et al. (2012) 'Access to oral health services for urban low-income Latino children: Social ecological influences', Journal of Public Health Dentistry, 72, pp. 8-18. doi: 10.1111/j.17527325.2011.00275.x.

Wong, R. C. P. and Szeto, W. Y. (2018) 'An alternative methodology for evaluating the service quality of urban taxis', Transport Policy, 69, pp. 132-140. doi: 10.1016/j.tranpol.2018.05.016.

World Health Organization (2018) Vulnerable groups. Available

at: http://www.who.int/environmental health emer gencies/vulnerable_groups/en/ (Āccesse-d: 10 July 2018).

Wulandari, R. D. et al. (2019) Socioeconomic Disparities in Hospital Utilization among Elderly People in Indonesia. Surabaya. doi: 10.13140/RG.2.2.11898.54721.

$\mathrm{Xu}, \mathrm{Y}$. et al. (2018) 'Catastrophic health expenditure in households with chronic disease patients: A pre-post comparison of the New Health Care Reform in Shaanxi Province, China', PLoS ONE, 13(3). doi: 10.1371/journal.pone.0194539.

Yildiz, M. S., Heboyan, V. and Khan, M. M. (2018) 'Estimating technical efficiency of Turkish hospitals: Implications for hospital reform initiatives', BMC Health Services Research, 18(1). doi: 10.1186/s12913-018-3239-y.

Yu, T.-H., Matthes, N. and Wei, C.-J. (2018) 'Can urban-rural patterns of hospital selection be changed using a report card program? A nationwide observational study', International Journal of Environmental Research and Public Health, 15(9). doi: 10.3390/ijerph15091827. 
Yuan, Y. et al. (2018) 'Socioeconomic and Geographic Disparities in Accessing Nursing Homes With High Star Ratings', Journal of the American
Medical Directors Association. doi: 10.1016/j.jamda.2018.05.017 